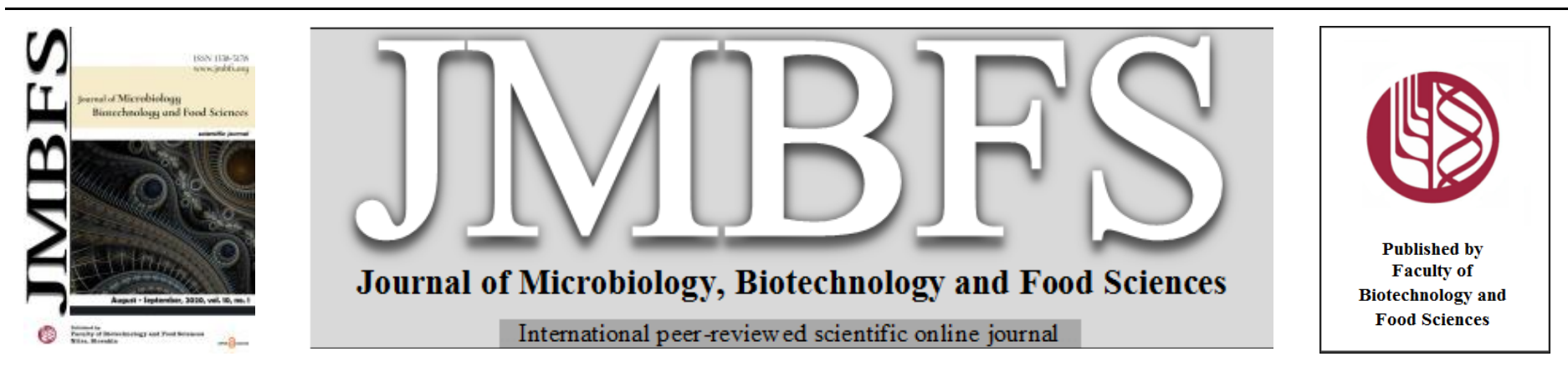

\title{
MORPHOGENESIS AND PATHOGENESIS REGULATION OF CANDIDA ALBICANS BY PROBIOTIC BACTERIUM - PEDIOCOCCUS ACIDILACTICI
}

\section{Zahra Zareshahrabadi ${ }^{1}$, Kamiar Zomorodian ${ }^{2,3}$, Keyvan Pakshir $^{2,3}$, Davood Mehrabani ${ }^{4}$, Hasti Nouraei ${ }^{3}$, Marjan Motamedi $^{3}$, Sassan Rezaie $^{* 1}$, Seyed Jamal Hashemi ${ }^{l}$, Alireza Ranjbaran ${ }^{5}$, Ladan Nazemi ${ }^{1}$, Kazem Ahmadikia ${ }^{1}$}

\author{
Address(es): Sassan Rezaie \\ ${ }^{1}$ Department of Parasitology and Mycology, School of Public Health, Tehran University of Sciences, Tehran, Iran. \\ ${ }^{2}$ Basic Sciences in Infectious Diseases Research Center, Shiraz University of Medical Sciences, Shiraz, Iran. \\ ${ }^{3}$ Department of Parasitology and Mycology, School of Medicine, Shiraz University of Medical Sciences, Shiraz, Iran. \\ ${ }^{4}$ Stem Cell and Transgenic Technology Research Center, Shiraz University of Medical Sciences, Shiraz, Iran. \\ ${ }^{5}$ Department of Oral and Maxillofacial Medicine, School of Dentistry, Shiraz University of Medical Sciences, Shiraz, Iran.
}

*Corresponding author: srezaie@tums.ac.ir

doi: $10.15414 / j m b f s .2020 .10 .1 .5-11$

\section{ARTICLE INFO}

Received 23. 1. 2019

Revised 21. 1. 2020

Accepted 19. 2. 2020

Published 1. 8. 2020

Regular article open 2 ACcess

\section{ABSTRACT}

The transition of Candida albicans from yeast to hyphae cause the attachment to epithelial cells, forming biofilm and invasion. Therefore, the effect of Pediococcus acidilactici on morphogenesis and pathogenesis of C. albicans were examined. Inhibitory activity of $P$. acidilactici on Candida species growth was investigated and inhibition of $C$. albicans biofilm formation was measured by XTT method. Also, expression of seven genes as: Agglutinin-like protein 1 (ALS1,3), hyphal cell-wall protein (HWP1), secreted aspartyl proteinase (SAP4,6), Enhanced filamentous growth 1 (EFG1) and Enhanced activated protein 1 (EAP1) were studied by RT-PCR with different concentrations of $P$. acidilactici. The experimental activity of this probiotic bacterium was evaluated in an animal model by culture and histopathological methods. P. acidilactici inhibited the growth of Candida species at concentrations of $8-512 \mu \mathrm{g} / \mathrm{mL}$ (approximately $8 \times 10^{6}$ to $5 \times 10^{8} \mathrm{CFU} / \mathrm{ml}$ ). This probiotic bacterium inhibited the germ tube and biofilm formation in a dose-dependent manner. RT-PCR analysis showed a reduction in genes expression. The $P$. acidilactici reduced the CFUs in mice receiving this probiotic bacterium. Histopathological analyses showed that Candida colonization was diminished in mice following the administration of probiotic. Since the wide range of antifungal activity of this bacterium bacterium, it can be used to manage oral candidiasis.

Keywords: Yeast; Probiotic bacteria; Gene expression; Antifungal activity; Animal model

\section{INTRODUCTION}

Recently, the prevalence of fungal infections has increased, mainly due to increased number of immunocompromised hosts, including individuals infected with HIV, transplant recipients and patients with cancer (Bongomin, Gago et al., 2017). Amongst fungal infections, candidiasis is one of the most common infection (Cheng, Yang et al., 2005, Mehta and Dave 2018). It might cause infections ranging from a simple superficial infection to a fatal candidemia. This infection is caused by Candida yeasts, as the normal flora of mucosal membranes (Guarana and Nucci 2017, Mehta and Dave 2018). Among Candida species, Candida albicans complex are the most common species that isolated from infections (Calderone and Fonzi 2001, Dewhirst, Chen et al., 2010). Despite their commensal nature, mucosal candidiasis such as gastrointestinal, respiratory, genital and oral candidiasis might disseminate toward a systemic infection (Gao, Xu et al., 2018). These yeasts can be isolated from the $20-80 \%$ of oral cavity healthy individuals, and in specific conditions, they might transform into a pathogen. Oral candidiasis is usually accompanied by severe inflammation and might affect the individuals quality of life (Gendreau and Loewy 2011). Oral candidiasis might cause discomfort, inflammation, pain, dysphagia, and disguise, present in three types i.e., erythematous, pseudomembranous and hyperplastic candidiasis. The conditions that predispose individuals to subsequent candidiasis are included but not limited to having HIV viruses, hyposalivation, diabetes mellitus, broad-spectrum antibiotics or immunosuppressive drugs, dentures, xerostomia (dry mouth syndrome), old age and poor oral hygiene (Martori, Ayuso-Montero et al., 2014, Manik and Bahl 2017). Adhesion is the first step to invade the host cell, followed by a transition from yeast to hyphal form and secretion of degradative enzymes, such as phospholipases and proteases to penetrate the tissue (Theberge, Semlali $\boldsymbol{e t}$ al., 2013). The above steps are regulated by gene expression, where ALS (Agglutinin-Like Sequence) genes are responsible for adhesion and biofilm formation, HWP1 (Hyphal Wall Protein 1) is a critical gene in transition from yeast to hypha and formation of biofilm,
EFG1 (Enhanced Filamentous Growth Protein 1) gene encodes a transcription factor essential for pathogenic hyphal state, and SAPs (Secretes Aspartic Proteinases ) gene family contribute to the virulence of these yeasts (Freire, de Barros et al., 2018). About 700 bacterial species and several fungal species are the known normal inhabitants of the oral cavity (Hager and Ghannoum 2017). These microorganisms might be organized either in biofilm structures or on mucosal surfaces (Kolenbrander, Palmer Jr et al., 2010). The proximity of these microorganisms in the oral cavity makes their interaction possible. It is facilitated through some secondary metabolites or microbial secretions (Morales and Hogan 2010). Previous studies showed that prescription of antibacterial antibiotics might predispose one to oral candidiasis, suggesting the importance of fungal and bacterial interaction in maintaining oral health (Diaz, Xie $\boldsymbol{e t}$ al. 2012). In other words, this interaction could balance their population (Harriott and Noverr 2011). Based on the WHO definition, probiotics are "live microorganisms that when administered or consumed in adequate quantities, confer health benefits on the host"(Morelli and Capurso 2012). Microorganisms belonging to the genera Lactobacillus, Bifidobacterium, Streptococcus, Enterococcus, and Saccharomyces have been used as an additive in food products (Chen, Kong $\boldsymbol{e t}$ al., 2010). These probiotics could help to balance $\mathrm{pH}$ tolerance, enhance the immune system through inducing secretion of immunoglobulin, inhibition of microbial pathogens overgrowth by secretion of secondary metabolites through competing to connect the host receptor (Rijkers, De Vos et al., 2011). Probiotics are not fungicidal but inhibit Candida adhesion (Vilela, Barbosa et al., 2015). Several clinical trials, animal experiments and laboratory studies have shown that probiotics might have a significant role in controlling fungal flora of the oral cavity (Guglielmetti, Taverniti et al., 2010). For example, Hatakka et al. (2007) in a randomized study, fed elderly participants with cheese that contain Lactobacillus and Propionibacterium probiotics and found that these probiotics led to $32 \%$ reduction in salivary yeast counts (Hatakka, Ahola et al., 2007). Similarly, Mendonca et al. (2012) showed that consumption of yogurt enriched with probiotics bacterium significantly decresed 
Candida population in healthy elderly (Mendonça, Santos et al., 2012). In another study, Kraft-Bodi et al. (2015) reported a significant reduction in the number of Candida in elderly fed with probiotic bacterium Lactobacillus reuter (Kraft-Bodi, Jørgensen et al., 2015). Moreover, in vivo studies suggested that fungal population in oral cavity might be modulated by probiotics. For example, Matsubara et al. (2012) showed that L. rhamnosus, reduced the C. albicans population in comparison with the untreated animal group (Matsubara, Silva $\boldsymbol{e}$ al., 2012). Ishijima et al. (2012) evaluated the ability of Streptococcus salivarius $K 12$, to modulate $C$. albicans growth. Ishijima reported that oral treatment with this probiotic protected the mice from candidiasis (Ishijima, Hayama et al., 2012). Zavisic et al. (2012) checked L. plantarum and L. Casei and reported thay this isolates have antagonistic action towards Staphylococcus aureus, Pseudomonas aeruginosa, Salmonella abony and Escherichia coli, but not have effect on the growth of $C$. albicans (Zavisic, Petricevic et al., 2012). However, limited information is available regarding $P$. acidilactici from Lactobacillaceae family. This Gram-positive cocci (often in pairs or tetrads) is a facultative anaerobe with the ability to tolerate a wide range of temperature (up to $65^{\circ} \mathrm{C}$ ) and $\mathrm{pH}$, osmotic pressure, lacking virulence factors that can survive in the GI tract (Salminen, von Wright et al., 1998, Borriello, Hammes et al., 2003, Balgir, Kaur et al., 2013, Fijan 2014). Moreover, this probiotic bacterium exhibit antibacterial activities against foodborne pathogens, such as Listeria monocytogenes, Salmonella enterica, Shigella sonnei, Klebsiella oxytoca, Enterobacter cloaca, and Streptococcus pyogenes (Albano, Todorov et al., 2007, Barbosa, Borges et al., 2015). Due to limited information on the interaction between fungi and bacteria, we indicated the inhibitory activity of $P$. acidilactici on the growth, germtube, biofilm formation and pathogenesis of Candida yeasts in the context of oral candidiasis.

\section{MATERIALS AND METHODS}

\section{Determining the antifungal activities}

\section{Preparation of microorganisms}

The antifungal effects of the $P$. acidilactici, against eleven American Type Culture Collection (ATCC) and CentraalBureau voorSchimmel cultures (CBS) strains of Candida, including C. albicans (CBS562, 1905, 1912, 1949, 2730, 5982), C. tropicalis (ATCC 750), C. krusei (ATCC 6258), C. glabrata (ATCC 90030), C. parapsilosis (ATCC 4344) and C. dubliniensis (CBS 8501) were determined. In addition, three clinical azole-resistant isolates of $C$. albicans were also examined in this study. A probiotic bacterium P. acidilactici (PTCC 1602) was supplied as a freeze-dried powder and cultivated in de man, rogosa and sharpe (MRS) broth medium (Merck, Berlin, Germany) at $37^{\circ} \mathrm{C}$, in an anaerobic incubator $(5 \% \mathrm{CO} 2)$ for $22 \mathrm{~h}$. The cells were harvested by centrifugation $(20000 \times \mathrm{g}$ for $5 \mathrm{~min})$ and washed twice in phosphate-buffered saline (PBS; pH 7.2). For quantification purposes, the bacterial cells were re-suspended in sterile distilled water and freeze-dried (Ishijima, Hayama et al., 2012). Moreover, to prepare cell-free supernatant (CFS), $P$. acidilactici was grown in sterile falcon tubes containing $10 \mathrm{~mL}$ of brain heart infusion (BHI) broth (Merck, Berlin, Germany) and the supernatant was collected by centrifugation (Labnet, seoul, Korea) at $18000 \times \mathrm{g}$ for $10 \mathrm{~min}$, and then sterilized by passing it through $0.2 \mu \mathrm{m}$ filter (Control Biogene, Madrid, Spain) (Zomorodian, Saharkhiz et al., 2011).

\section{Antimicrobial susceptibility tests}

Antifungal susceptibility test was performed by broth microdilution method with the Clinical and Laboratory Standards Institute reference method (CLSI document M27-A3). To determine antifungal activities of this probiotic bacteria, serial dilutions of the probiotic bacterium $(1-512 \mu \mathrm{g} / \mathrm{mL})$ (approximately $1 \times 10$ to $5 \times 10^{8} \mathrm{cfu} / \mathrm{ml}$ ) were prepared in 96 -well microtiter plates using RPMI-1640 media (Sigma, St. Louis, MO, United States) buffered with MOPS (Sigma, St. Louis, MO, USA). The yeasts strains suspension was adjusted at $530 \mathrm{~nm}$ wavelengths by spectrophotometric method $\left(2 \times 10^{8} \mathrm{cfu} / \mathrm{ml}\right)$. Then $0.1 \mathrm{~mL}$ of this suspension was added to the microtiter plates and incubated at $30^{\circ} \mathrm{C}$ for $24-48 \mathrm{~h}$. Uninoculated medium $(200 \mu \mathrm{L})$ was included as a sterility control (blank). The fluconazole (Sigma, USA) ranging from 0.125 to $64 \mu \mathrm{g} / \mathrm{mL}$ was used as positive control. Also, growth controls (media and inoculums with-out $P$. acidilactici) were also included. The growth in wells was compared with controls. Minimum inhibitory concentrations (MICs) were visually analyzed and defined as the lowest inhibitory concentration of the $P$. acidilactici that produced $\geq 99 \%$ growth inhibition for yeasts in comparison with the growth in the control wells. Each test was did in triplicates (Zomorodian, Saharkhiz et al., 2011).

Determining the antibiofilm activity against $C$. albicans.

\section{Biofilm preparation and growth}

Standard strains of $C$. albicans (CBS 5982), were cultured on sabouraud dextrose agar (SDA) (Merck, Germany). After 48 h one loop of the C. albicans colonies was transferred to $20 \mathrm{~mL}$ sabouraud dextrose broth (Merck, Berlin, Germany) and incubated at $30^{\circ} \mathrm{C}$ on shaker at $100 \mathrm{rpm}(24 \mathrm{~h})$. Then the yeast cells were washed twice in sterile PBS $(0.8 \%$ [w/v], $\mathrm{NaCl}$ (Merck, Berlin, Germany); $0.02 \%$ [w/v], $\mathrm{KH}_{2} \mathrm{PO}_{4}$ (Merck, Berlin, Germany); 0.31\% [w/v], $\mathrm{Na}_{2} \mathrm{HPO}_{4}+12 \mathrm{H}_{2} \mathrm{O}$ (Merck, Berlin, Germany); 0.02\% [w/v], KCl (Panreac, Madrid, Spain); pH 7.4, then washed yeast cells were re-suspended in RPMI 1640. The cell dencities were adjusted to $1.0 \times 10^{8}$ cells $/ \mathrm{mL}$ at the wavelength of $530 \mathrm{~nm}$. Serial dilutions of the $P$. acidilactici $(0.25$ to $256 \mu \mathrm{g} / \mathrm{mL})$ were prepared in 96 -well plates by RPMI-1640 media. After adding the $0.1 \mathrm{~mL}$ of yeast cells to the wells, plates were incubated at $30^{\circ} \mathrm{C}$ for $48 \mathrm{~h}$. In addition, $200 \mu \mathrm{L}$ of the RPMI- 1640 media was used as the negative control (blank) and RPMI-1640 with the yeasts, without the $P$. acidilactici considered as positive controls (Zomorodian, Saharkhiz et al., 2018).

\section{Assessing biofilm formation}

Biofilm formation was assessed, by using a 2,3-bis (2-methoxy-4-nitro-5-sulfophenyl)-2H-tetrazolium-5-carbox-anilide (XTT) reduction assay (Zomorodian, Saharkhiz et al., 2018). XTT (Sigma Chemical Co., St. Louis, USA) was prepared in Ringers lactate $(0.5 \mathrm{mg} / \mathrm{mL})$. The solution was filter-sterilized $\left(0.22 \mu \mathrm{m}\right.$-pore-size), then stored at $-70^{\circ} \mathrm{C}$. Prior to each assay, XTT stock solution was mixed with menadione sodium bisulfite $(10 \mathrm{mM}$, Sigma Chemical Co., St. Louis, USA). After $48 \mathrm{~h}$ of incubation, the biofilms were washed twice with a sterile PBS and then $100 \mu \mathrm{L}$ aliquot of XTT/menadione was added to each well of 96 -well plates. The plates were incubated at $37^{\circ} \mathrm{C}$ in a dark room (2h). Finally, the colorimetric changes were detected at $570 \mathrm{~nm}$ by using a microplate reader (BMG Labtech, Berlin, Germany) (Zomorodian, Saharkhiz et al., 2018).

\section{Germ tube formation and mycelial growth of $C$. albicans:}

(i) Germ tube formation analysis: $100 \mu \mathrm{L}$ of both RPMI-1640 enriched with sheep serum were inoculated into 96-well microtiter plates. Freeze-dried $P$. acidilactici powder was added to each well to reach $1-512 \mu \mathrm{g} / \mathrm{mL}$ concentration, then $100 \mu \mathrm{L}$ of $C$. albicans suspension with the concentration of $2 \times 10^{8}$ cells $/ \mathrm{mL}$ was added and incubated at $37^{\circ} \mathrm{C}$ for $3 \mathrm{~h}$. After staining with calcofluor white (Sigma, USA) germ tube formation was measured under fluorescence microscopy.

(ii) Inhibition of mycelial growth by $P$. acidilactici also was carried out similar to that of the germ tube inhibition test, but with a longer incubation period (i.e., 24h) (Ishijima, Hayama et al., 2012).

\section{Quantitative real-time polymerase chain reaction (Q-PCR)}

To detect the effect of $P$. acidilactici on the transcription of $C$. albicans genes related to adhesion and invasion, quantitative real-time reverse transcription PCR (QRT-PCR) was performed as described before (K. M. James). For this purpose C. albicans (CBS1912) was sub-cultured as previously described to reach an exponential phase. Then $2 \times 10^{8}$ cells $/ \mathrm{mL}$ of $C$. albicans was suspended in RPMI-1640 media in $1.5 \mathrm{~mL}$ microcentrifuge tubes and treated as follows: $C$. albicans suspension with (i) fluconazole at $2 \mu \mathrm{g} / \mathrm{mL}$ in $450 \mu \mathrm{L}$ RPMI-1640 media (positive control), (ii) $P$. acidilactici at $8,16,32,64,512 \mu \mathrm{g} / \mathrm{mL}$, (iii) $450 \mathrm{~mL}$ RPMI 1640 media alone as negative control. Following $6 \mathrm{~h}$ incubation at $37^{\circ} \mathrm{C}$ and $5 \% \mathrm{CO} 2$, the cells were collected by centrifugation for $5 \mathrm{~min}$ at $12000 \times \mathrm{g}$.

Table 1 Primer sequences

\begin{tabular}{|c|c|}
\hline Gene & Primer sequence \\
\hline \multirow[t]{2}{*}{ ACT1 } & F: GCTGGTAGAGACTTGACCAACCA \\
\hline & R:GACAATTTCTCTTTCAGCACTAGTAGTGA \\
\hline \multirow{2}{*}{ ALS1 } & F:CCTATCTGACTAAGACTGCACC \\
\hline & R:ACAGTTGGATTTGGCAGTGGA \\
\hline \multirow[t]{2}{*}{ ALS3 } & F:AATGGTCCTTATGAATCACCATCTACTA \\
\hline & R:GAGTTTTCATCCATACTTGATTTCACAT \\
\hline \multirow{2}{*}{ HWP1 } & F:CTCCAGCCACTGAAACCACCA \\
\hline & R:GGTGGAATGGAAGCTTCTGGA \\
\hline \multirow[t]{2}{*}{ EAP1 } & F:CTGCTCACTCAACTTCAATTGTCG \\
\hline & R:GAACACATCCACCTTCGGGA \\
\hline \multirow[t]{2}{*}{ EFG1 } & F:TATGCCCCAGCAAACAACTG \\
\hline & R:TTGTTGTCCTGCTGTCTGTC \\
\hline \multirow[t]{2}{*}{ SAP4 } & F:AGATATTGAGCCCACAGAAATTCC \\
\hline & R:CAATTTAACTGCAACAGGTCCTCTT \\
\hline \multirow[t]{2}{*}{ SAP6 } & F:TTACGCAAAAGGTAACTTGTATCAAGA \\
\hline & R:CCTTTATGAGCACTAGTAGACCAAACG \\
\hline
\end{tabular}

Then, the supernatant was discarded and RNA isolated, using RNeasy KIT (QIAGEN, Valencia, CA, USA). Concentration of the isolated RNA samples were determined by a Nanodrop spectrophotometer (Thermo Scientific, USA). Complementary DNA (cDNA) was produced from the isolated RNAs by the cDNA synthesis kit (Fermentas, Canada). Approximately $2 \mu \mathrm{L}$ cDNA was amplified in each $25 \mu \mathrm{L}$ PCR reaction mix containing $12.5 \mu \mathrm{L}$ of $2 \mathrm{X}$ SYBR Green Master Mix (Applied Biosystems, USA), $0.2 \mu \mathrm{L}$ of each 10 pmol forward and reverse primers (Designed in primer 3 software, Tab 1) and $10.1 \mu \mathrm{L}$ DEPC treated 
water. QRT-PCRs were carried out on ABI-7500-Real-time PCR system (Applied-Biosystems, USA). PCR was done in 45 cycles: $95^{\circ} \mathrm{C}$ for $10 \mathrm{~min}, 95^{\circ} \mathrm{C}$ for $15 \mathrm{~s}, 60^{\circ} \mathrm{C}$ for $60 \mathrm{~s}$ and $60^{\circ} \mathrm{C}$ for $45 \mathrm{~s}$. All data were compared to the beta-actin house-keeping gene. Genes relative expressions were determined using $2^{-\Delta \Delta C T}$ method (Theberge, Semlali et al., 2013, James, MacDonald et al., 2016).

Experimental model of oral candidiasis

\section{Inducing oral candidiasis}

Thirty, 6-week-old female mice weighing 22-25 grams (BALB/c) were used for this experiment. All experiments were done in according with the Guiding Principles for the Care and Use of Animals in the Field of Physiological Sciences (Aftanas and Golosheikin 2002) (Ethical code IR. Shiraz University of Medical Sciences : SUMS.REC.1397.640). Mice were randomized and kept in caged housing 3 to 4 animals in pathogen-free conditions, and fed with autoclavesterilized and dried food and water during the experiments. The temperature was adjusted at $21^{\circ} \mathrm{C}$. Oral candidiasis was induced according to the protocol described by Ishijima et al. (2012). In short, $15 \mathrm{mg} / \mathrm{mL}$ of tetracycline hydrochloride (Hakim Pharmaceutical Company, Shiraz, Iran) was administered through drinking water of mice for $24 \mathrm{~h}$. Then, to induce an immunosuppressed condition, $100 \mathrm{mg} / \mathrm{Kg}$ of prednisolone (Hakim Pharmaceutical Company, Shiraz, Iran) was injected subcutaneously $24 \mathrm{~h}$ prior to oral inoculation of $C$. albicans Then, the oral cavity of mice was inoculated by means of a cotton swab (Talaye Teb Azma Company, Shiraz, Iran) soaked in $2.0 \times 10^{8} \mathrm{CFU} / \mathrm{mL}$ of C. albican (CBS1912). With the difference in the number of yeast grown from swabs before and after inoculation, the number of yeast in the oral cavity of the mice was counted and estimated to be $1 \times 10^{6} \mathrm{CFU} /$ mouse (Ishijima,Hayama et al., 2012).

\section{Probiotic treatment}

Mice were divided into three treatment groups of Probiotics $(n=20)$, Fluconazole $(\mathrm{n}=5)$ and Negative control $(\mathrm{n}=5)$. In probiotic group, fifty microliters of $P$. acidilactici in D.W. was inoculated into the oral cavity in different concentrations $(7.5,15,30$ and $60 \mathrm{mg} / \mathrm{mL})$ at five-time intervals including $24 \mathrm{~h}$ and $3 \mathrm{~h}$ before and 3, 24, and $27 \mathrm{~h}$ after $C$. albicans inoculation. Moreover, the same volume of fluconazole $(2 \mathrm{mg} / \mathrm{mL})$ and D.W. was orally administered for the fluconazole and control groups, respectively. Mice were sacrificed $48 \mathrm{~h}$ after last time inoculation of probiotics bacteria for further experiments described below.

\section{Evaluating the count of viable Candida cells}

After $48 \mathrm{~h}$ of inoculation, the oral cavity was completely swabbed by fine-tipped cotton swab. For this purpose, the swab was placed in a falcon tubes containing 3 $\mathrm{mL}$ of sterile normal saline. Then, the cells were suspended by a vortex. Fifty microliters of each sample were cultured on a sabouraud dextrose agar plate and the number of $\log _{10} \mathrm{CFU}$ of Candida per swab in each group were counted and compared.

\section{Histopathological evaluation}

For morphological observation, the mice tongues were cut off and fixed in 4\% paraformaldehyde ( $\mathrm{pH}$ 7.4) PBS, dehydrated by ethanol series, and embedded in paraffin. The yielded paraffin blocks were then sectioned and deparaffinized, and finally stained with Periodic acid-Schiff (PAS) and hematoxylin-eosin (H\&E) Finally, the slides were evaluated by a pathologist to detect any infection (Elahi, Pang et al., 2005, Ishijima, Hayama et al., 2012).

\section{Statistical analyses}

The results were evaluated with significant differences $(P$-value $<0.05)$ and compared with no $P$. acidilactici (control), as determined using One-Way ANOVA test.

\section{RESULT}

\section{Antifungal activity of probiotics}

Antifungal activity of probiotic bacterium $P$. acidilactici against Candida species was determined by the broth microdilution method. As shown in Tab 2, the probiotics exhibited the inhibitory activity against the tested yeasts at 8-512 $\mu \mathrm{g} / \mathrm{mL}$ concentrations (geometric mean $=78.01 \mu \mathrm{g} / \mathrm{mL}$ ). Moreover, the probiotics inhibited the growth of azole-resistant strains at concentrations of 256-512 $\mu \mathrm{g} / \mathrm{mL}$.
Table 2 Results of $P$. acidilactici antifungal activity by broth microdilution method

\begin{tabular}{lccc}
\hline Isolates & ATCC/CBS & $\begin{array}{c}\text { Probiotic } \\
\text { MIC } \\
(\boldsymbol{\mu g} / \mathbf{m L})\end{array}$ & $\begin{array}{c}\text { Fluconazole } \\
\text { MIC } \\
(\boldsymbol{\mu g} / \mathbf{m L})\end{array}$ \\
\hline C.albicans & $562(\mathrm{CBS})$ & 64 & 4 \\
\hline C.albicans & $1905(\mathrm{CBS})$ & 128 & 8 \\
\hline C.albicans & $1912(\mathrm{CBS})$ & 32 & 4 \\
\hline C.albicans & $1949(\mathrm{CBS})$ & 64 & 2 \\
\hline C.albicans & $2730(\mathrm{CBS})$ & 64 & 4 \\
\hline C.albicans & $5982(\mathrm{CBS})$ & 128 & 8 \\
\hline C.albicans & SUMS-8808 & 256 & 64 \\
\hline C.albicans & SUMS-2302 & 512 & 64 \\
\hline C.albicans & SUMS-625 & 256 & 128 \\
\hline C.dubliniensis & $8501(\mathrm{CBS})$ & 32 & 2 \\
\hline C.tropicalis & $750(\mathrm{ATCC})$ & 32 & 32 \\
\hline C.parapsilosis & $4344(\mathrm{ATCC})$ & 8 & 2 \\
\hline C.krusei & $6258(\mathrm{ATCC})$ & 64 & 64 \\
\hline C.glabrata & $90030(\mathrm{ATCC})$ & 128 & 32 \\
\hline A. &
\end{tabular}

Abbreviations: MIC, Minimum Inhibitory Concentration, ATCC, American Type Culture Collection; CBS, CentraalBureau voor Schimmelcultures

\section{Biofilm formation Inhibition}

Formation of C. albicans biofilm in the presence of P.acidilactic at $0-256 \mu \mathrm{g} / \mathrm{mL}$ concentrations was measured quantitatively by XTT reduction assay (Tab 3). As shown in figure 1 , the formation of biofilm was inhibited by $P$. acidilactici up to $63 \%$ and $82.52 \%$ after 24 and $48 \mathrm{~h}$, respectively. Indeed, $P$. acidilactici exhibited significant activity in the inhibition of biofilm formation as reflected by lower absorbance reading when compared with the untreated control.

Table 3 biofilm formation of $C$. albicans in different concentrations $P$. acidilactici by XTT reduction assay

\begin{tabular}{lcccc}
\hline \multirow{2}{*}{$\begin{array}{l}\text { Probiotic } \\
\text { concentration }(\mu \mathrm{g} / \mathrm{mL})\end{array}$} & \multicolumn{2}{c}{ Optical density $\pm \mathrm{SD}$} & \multicolumn{2}{c}{ Biofilm formation } \\
\cline { 2 - 5 } & $24 \mathrm{~h}$ & $48 \mathrm{~h}$ & $24 \mathrm{~h}$ & $48 \mathrm{~h}$ \\
\hline $\mathbf{0}$ & $0.150 \pm 0.004$ & $0.220 \pm 0.004$ & 100 & 100 \\
\hline $\mathbf{0 . 5}$ & $0.138 \pm 0.004$ & $0.165 \pm 0.003$ & 92.1 & 75.12 \\
\hline $\mathbf{1}$ & $0.128 \pm 0.003$ & $0.160 \pm 0.003$ & 85.33 & 72.6 \\
\hline $\mathbf{2}$ & $0.115 \pm 0.002$ & $0.130 \pm 0.002$ & 76.6 & 59.5 \\
\hline $\mathbf{4}$ & $0.092 \pm 0.002$ & $0.112 \pm 0.003$ & 61.12 & 50.12 \\
\hline $\mathbf{8}$ & $0.080 \pm 0.003$ & $0.100 \pm 0.002$ & 53.33 & 45.23 \\
\hline $\mathbf{1 6}$ & $0.079 \pm 0.003$ & $0.099 \pm 0.003$ & 52.6 & 45.17 \\
\hline $\mathbf{3 2}$ & $0.075 \pm 0.004$ & $0.090 \pm 0.003$ & 50.0 & 40.11 \\
\hline $\mathbf{6 4}$ & $0.063 \pm 0.004$ & $0.065 \pm 0.004$ & 42.0 & 29.13 \\
\hline $\mathbf{1 2 8}$ & $0.060 \pm 0.003$ & $0.045 \pm 0.002$ & 40.0 & 20.3 \\
\hline $\mathbf{2 5 6}$ & $0.055 \pm 0.003$ & $0.040 \pm 0.003$ & 36.66 & 18.5 \\
\hline SD: St & & & &
\end{tabular}

SD: Standard Deviation

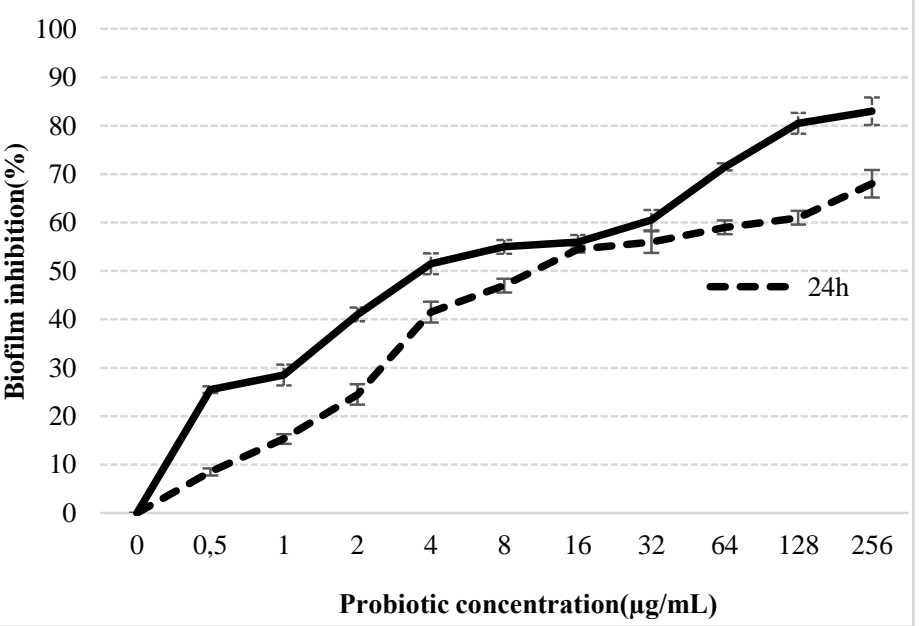

Figure 1 Inhibition of Candida biofilm formation in different concentrations of P. acidilactici 
Microscopic evaluation of germ tube and mycelial formation of $C$. albicans:

In this study, $70 \%$ of C. albicans cells produced germ tube in serum-enriched RPMI-1640, while the number of yeast formed germ tube reduced to $16 \%$ at 512 $\mu \mathrm{g} / \mathrm{mL}$ of the probiotic bacterium. As shown in figure 2 and 3, formations of germ tubes were inhibited by $P$. acidilactici up to $77 \%$ in a dose-dependent manner.

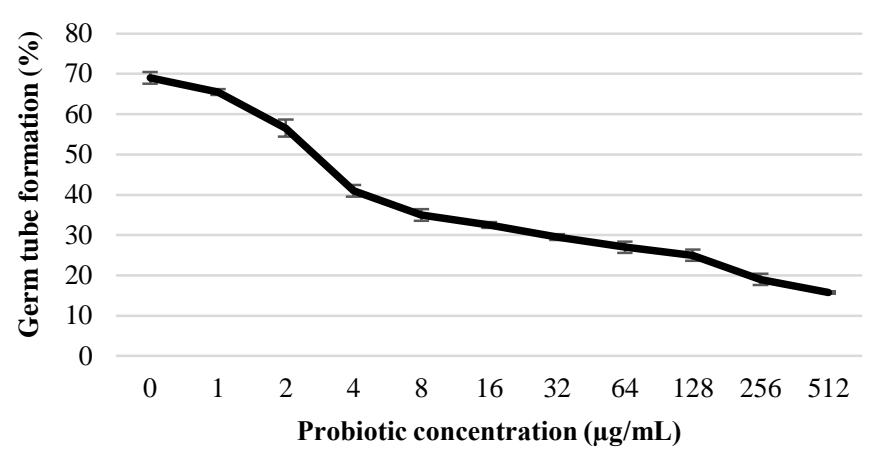

Figure 2 Candida germ tube formation in different concentrations of $P$. acidilactici
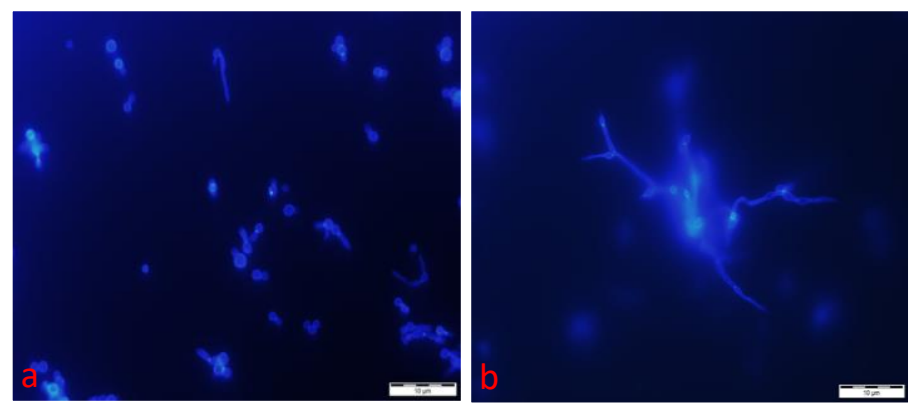
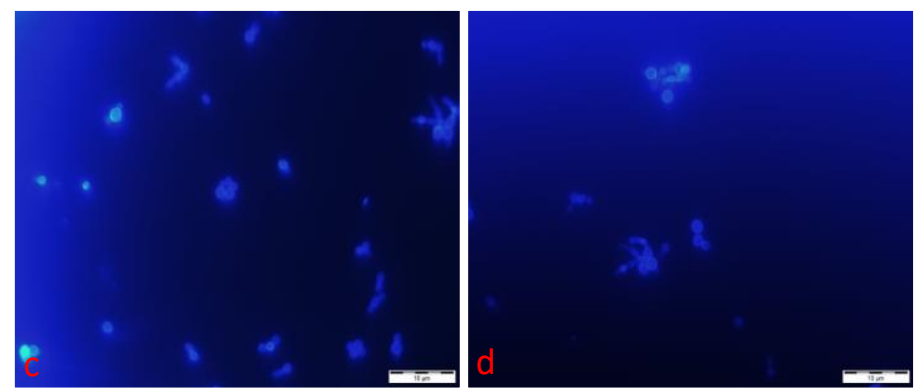

Figure 3 Hyphal and mycelial form of untreated C. albicans in serum-enriched RPMI-1640 (a, b) and in serum-enriched RPMI-1640 containing $512 \mu \mathrm{g} / \mathrm{mL}$ of $P$. acidilactici $(\mathrm{c}, \mathrm{d})$

\section{Modulating the expression of $C$. albicans genes expression in different concentrations of $P$. acidilactici}

The expression of various genes involved in C. albicans growth, adhesion and invasion following treatment in different concentrations of $P$. acidilactici are shown in Tab 4. Following exposure of $C$. albicans to $P$. acidilactici for $6 \mathrm{~h}$, HWP1 gene was considerably down-regulated in a dose-dependent manner. This reduction was significant in comparison with fluconazole and untreated $C$. albicans. In the same line, SAPs 4,6 were both down-regulated by the treatment in different concentrations of $P$. acidilactici. Additionally, the EAP1 gene, which encodes a glycosyl phosphatidylinositol anchored, glucan-cross linked cell wall protein was also affected by this treatment. EFG1 is another gene reduced up to $50 \%$ at a concentration of $512 \mu \mathrm{g} / \mathrm{mL}$ of the probiotics. Moreover, the downregulation in the expression of ALS1 and 3 indicated the role of probiotics in reducing virulence and subsequent dissemination capability of $C$. albicans. This phenomenon was observed in different concentrations of $P$. acidilactici.

Table 4 Gene expression of $C$. albicans treated $(6 \mathrm{~h})$ under non-hyphae inducing culture in different concentrations of $P$. acidilactici.

\begin{tabular}{|c|c|c|c|c|c|c|c|}
\hline \multirow[b]{2}{*}{ Gene } & \multirow{2}{*}{$\begin{array}{l}\text { Untreated } \\
\text { C. albicans }\end{array}$} & \multirow{2}{*}{$\begin{array}{c}\text { Fluconazole } \\
(2 \mathrm{mg} / \mathrm{mL})\end{array}$} & \multicolumn{5}{|c|}{ P. acidilactici } \\
\hline & & & $8 \mu \mathrm{g} / \mathrm{ml}$ & $16 \mu \mathrm{g} / \mathrm{ml}$ & $32 \mu \mathrm{g} / \mathrm{ml}$ & $128 \mu \mathrm{g} / \mathrm{ml}$ & $512 \mu \mathrm{g} / \mathrm{ml}$ \\
\hline ALS1 & 0.98 & 0.54 & $0.5 * *$ & $0.49 * *$ & $0.3 * *$ & $0.36 * *$ & $0.23 * *$ \\
\hline ALS3 & 1.0 & 0.2 & $0.4^{* *}$ & $0.39 * *$ & $0.35 * *$ & $0.26^{* *}$ & $0.26^{* *}$ \\
\hline HWP1 & 1.0 & 0.12 & $0.4^{* *}$ & $0.31 * *$ & $0.27 * *$ & $0.12 * *$ & $0.09^{* *}$ \\
\hline SAP4 & 1.0 & 0.42 & 0.8 & $0.76^{*}$ & $0.69 *$ & $0.59 *$ & $0.51^{* *}$ \\
\hline SAP6 & 0.97 & 0.6 & 0.9 & $0.88^{*}$ & $0.78^{*}$ & $0.78^{*}$ & $0.6^{* *}$ \\
\hline EFG1 & 1.0 & 0.4 & 0.82 & $0.73^{*}$ & $0.65 * *$ & $0.56^{* *}$ & $0.5^{* *}$ \\
\hline EAP1 & 1.0 & 0.39 & 0.8 & $0.72 *$ & $0.65^{*}$ & $0.59 * *$ & $0.56^{* *}$ \\
\hline
\end{tabular}

C. albicans was cultured in RPMI-1640 medium with or without (untreated control) $P$. acidilactici at various concentrations. Culture in the presence of 2 mg/mL fluconazole was served as the positive controls $(* \mathrm{p}$-value $<0.05$, ** $\mathrm{p}$-value $\leq 0.001)$.

\section{Effect of $P$. acidilactici on oral candidiasis model.}

The effects of $P$. acidilactici on murine oral candidiasis were examined. $P$. acidilactici was orally administrated at 24 and $3 \mathrm{~h}$ before and 3, 24, and $27 \mathrm{~h}$ after Candida inoculation. It appeared that $P$. acidilactici treatment caused a dosedependent reduction in clinical manifestation. One-way analysis of data indicated significant differences in the Candida burden of the tongue between mice treated in different concentrations $P$. acidilactici ( $p$-value $<0.05$ ) (Fig.4). In histopathological analysis it was shown that the oral inoculation of $50 \mu 1$ of $P$. acidilactici with concentration of $7.5 \mathrm{mg} / \mathrm{mL}$ resulted in no significant difference in clinical manifestation from the D.W. control group, oral administration of 15 , 30 and $60 \mathrm{mg} / \mathrm{mL}$ of this probiotics bacterium resulted in a significant difference from the D.W. control group (Fig.5).

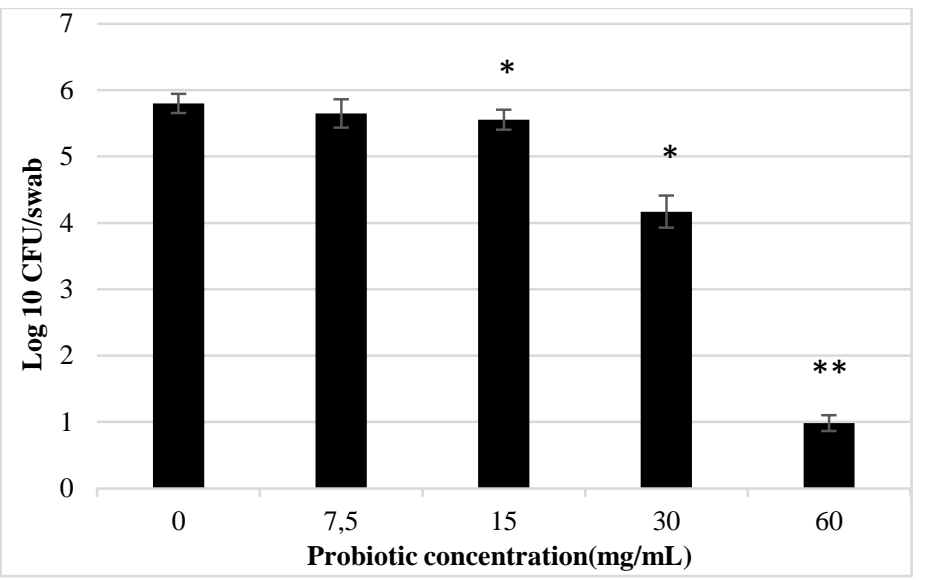

Figure 4 Fungal burden (log $10 \mathrm{CFU} / \mathrm{swab})$ of Candida on oral cavity of mice treated in different concentrations of $P$. acidilactici ${ }^{*} p$-value $<0.05$, ** $p$-value $\leq 0.001)$. 


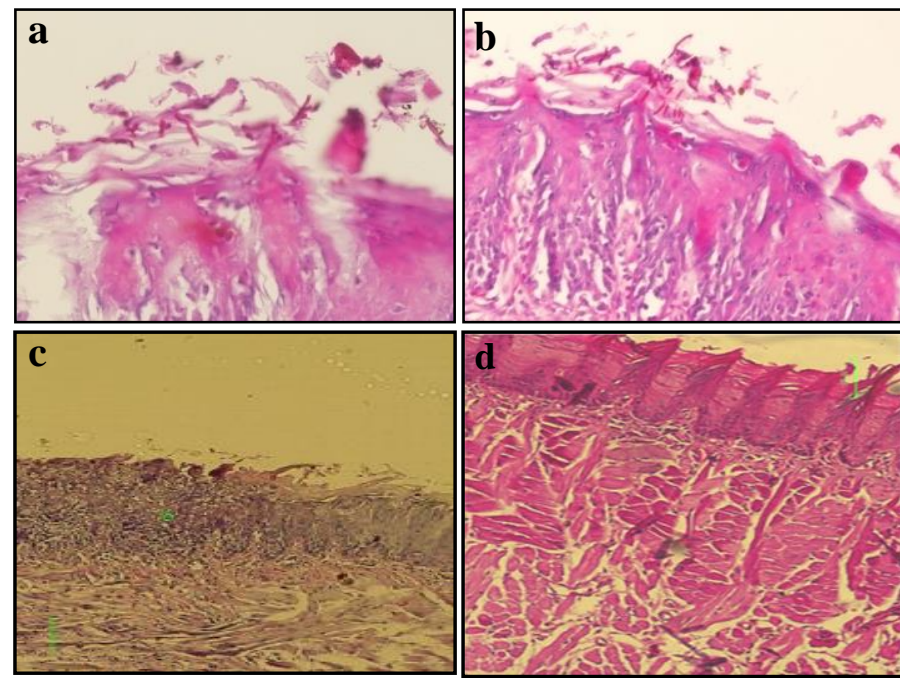

Figure 5 (a,b). Untreated control, significant inflammation and presence of $C$ albicans dispersed in tissue, lymphatic dilation, and edema (PAS,40x) (c) Treated with $15 \mathrm{mg} / \mathrm{mL} P$. acidilactici, few inflammation and $C$. albicans $(\mathrm{H} \& \mathrm{E}, 100 \mathrm{x})(d)$. Treated with $60 \mathrm{mg} / \mathrm{mL}$ P. acidilactici absence of inflammation and $C$. albicans beginning of healing in tissue $(\mathrm{H} \& \mathrm{E}, 100 \mathrm{x})$.

\section{DISCUSSION}

The trans-kingdom interaction between yeasts and bacteria have gained interest in recent researches. These synergistic or antagonistic microbial interactions can modulate the virulence of pathogenic microorganisms and pathogen-host immune responses (Diaz, Strausbaugh et al., 2014). More importantly, recent researches indicated that bacteria might play a significant role in the $C$. albicans infections For example, prior urinary tract infection with Escherichia coli was found to improve adhesion of yeast to bladder mucous and increase the likelihood of candidiasis (Levison and Pitsakis 1987). In contrast, indigenous bowel microbial population reduced the adhesion of $C$. albicans to the alimentary surface of hamsters and competing with yeast cells by attaching to the mucosa receptors (Kennedy and Volz 1985, Shirtliff, Peters et al., 2009). P. acidilactici inhibited the Candida species growth at 8 to $512 \mu \mathrm{g} / \mathrm{mL}$ concentrations. Our finding is in line with studies that reported the inhibitory activities of different probiotic bacteria against Candida species (Köhler, Assefa et al., 2012, Kheradmand, Rafii et al., 2014, Jiang, Stamatova et al., 2015, Shokryazdan, Jahromi et al., 2017, Biyari and Fozouni 2018). Whilst, Koll et al. (2008) found no antifungal activity of lactobacillus species against Candida species (Koll, Mandar et al., 2008). The difference between MICs of our study with those of previous reports might be due to the differences in probiotic bacteria tested or the methods of determining the antimicrobial susceptibility (Hasslöf, Hedberg et al., 2010, Köhler, Assefa et al., 2012). As $P$. acidilactici inhibited the growth of azole-resistant isolates of $C$. albicans, its mechanism of action might be different from that of azole drugs. Microbial biofilm provides a niche for oral pathogens. Previous studies indicated that single or multispecies Candida biofilms might be relevant to antifungal therapies resistance (MontelongoJauregui, Srinivasan et al., 2016, Montelongo-Jauregui, Srinivasan et al., 2018). It is noteworthy that, some studies have shown that after adhering of oral microorganisms to Candida in biofilm context, its pathogenicity might be amending (Radford, Challacombe et al., 1999, Diaz, Xie et al., 2012). In our study, $P$. acidilactici inhibited the $C$. albicans biofilm formation. Our results supported other previous studies findings, which showed inhibition of biofilm formation through the implication of probiotics bacteria (Hatakka, Ahola et al., 2007, Ishijima, Hayama et al., 2012, James, MacDonald et al., 2016) Additionally, the formation of the germ tube and hyphae was inhibited significantly by $P$. acidilactici, which is in line with Ishijima et al study (Ishijima, Hayama et al., 2012). Consistent with morphological methods (i.e., XTT), expression of genes recognized to have a role in morphogenesis and formation of biofilm, which were significantly down-regulated upon treatment of yeast cells with $P$. acidilactici. Comparable results were described by James et al., (2016) which showed that down-regulation of genes responsible for biofilm formation in $C$. albicans cells following treatment with $L$. plantarum, $L$. helveticus, and Streptococcus salivarius (James, MacDonald et al., 2016). Of gene regulating the cell wall dynamics in $C$. albicans EFG1 encodes a transcription factor called Efg1p (Desai, Lengeler et al., 2018). Regarding the significant reduction of this gene expression following treatment with $P$. acidilactici, a probable mechanism might be the inhibition of cAMP-Efg1p in yeasts (Huang, Huang et al., 2018). EFG1 is a well-known regulatory gene, that important for the transcription of hyphae-specific genes. Therefore, by reducing the expression of this gene in probiotics treated Candida cells might lead to down-regulation of HWP1, which is essential for the growth of a mycelial form of $C$. albicans and adhesion to the host cells (Sharkey, McNemar et al., 1999,
Orsi, Borghi et al., 2014). Moreover, EAP1 expression, also regulated by EFG1, reduced by this probiotics, might lead to a decline in pathogenesis by reducing binding to host cells ( $\mathbf{L i}$ and Palecek 2003). ALS1, 3 that mediate yeast adhesion to epithelial, endothelial and extracellular cells. They bind to cell receptors, such as E-cadherin and N-cadherin, and induce endocytosis of the microorganism (Liu and Filler 2011). These two genes expressions are responsible for Candida pathogenicity, which was reduced by different concentrations of $P$. acidilactici. Additionally, two SAP genes expression, SAP4, and SAP6, which are known to have a role in degrading components of host immune cell membranes (Staniszewska, Bondaryk et al., 2014) decreased by probiotics treatment in hyphal induced condition. In addition to the in vitro experiments, our experimental murine model of oral candidiasis showed that feeding live $P$. acidilactici to mice infected with $C$. albicans orally protects them against oral candidiasis. The clearance of $C$. albicans from the oral cavity of BALB/c mice fed with $P$. acidilactici increased significantly, which is in line with our invitro results. These results support a previous report by Kraft-bodi and Ishijima, which showed that probiotic bacterium may protect immunosuppressed mice from systemic candidiasis (Ishijima, Hayama et al., 2012, Kraft-Bodi, Jørgensen et al., 2015).

\section{CONCLUSION}

Concerning inhibitory activities of this probiotics bacterium against formation of Candida biofilm and germ tube, they might be used to protect the host from oral candidiasis and reducing the symptoms and fungal burden in the oral cavity. As this non-pathogenic probiotic bacterium is a part of the GRAS bacteria, it is possible to use it in the food industry. Adding a pleasant flavor and texture to dairy, vegetable and meat products as well as increasing nutritional value and digestibility of foodstuffs are an additional bonus to its antifungal properties. Moreover, instead of chemical preservatives this probiotic bacterium might be used in food and feed industry.

Acknowledgment: This study was supported by the Tehran University of Medical Sciences. The authors wish to thank Mr. H. Argasi at the Research Consultation Center (RCC) of Shiraz University of Medical Sciences for editing this manuscript.

\section{REFERENCES}

Aftanas, L., \& Golosheikin, S., 2002. Guiding principles for the care and use of animals in the field of physiological sciences. Nippon Seirigaku Zasshi.64:143-6. Albano, H., Todorov, S. D., Van Reenen, C. A., Hogg, T., Dicks, L. M., \& Teixeira, P., 2007. Characterization of two bacteriocins produced by Pediococcus acidilactici isolated from "Alheira", a fermented sausage traditionally produced in Portugal. Int J Food Microbiol. 116(2), 239-247. https://doi.org/10.1016/j.ijfoodmicro.2007.01.011

Balgir, P. P., et al. (2013). In vitro and in vivo survival and colonic adhesion of Pediococcus acidilactici MTCC5101 in human gut. Biomed Res Int. 2013. http://dx.doi.org/10.1155/2013/583850

Borriello, S., et al. (2003). Safety of probiotics that contain lactobacilli or bifidobacteria. Clin. Infect. Dis. 36(6): 775-780. https://doi.org/10.1086/368080

Barbosa, J., Borges, S., \& Teixeira, P., 2015. Pediococcus acidilactici as a potential probiotic to be used in food industry. Int J Food Sci Technol. 50(5), 1151-1157. https://doi.org/10.1111/ijfs.12768

Biyari, S., \& Fozouni, L., 2018. The Inhibitory Effect of Probiotic Bacteria against Drug-Resistant Candida Species Isolated from the Oral Cavity of the Elderly. Shiraz E-Med J. 19(6). https://doi: 10.5812/semj.62026.

Bongomin, F., Gago, S., Oladele, R. O., \& Denning, D. W., 2017. Global and multi-national prevalence of fungal diseases - estimate precision. J Fungi (Basel) . 3. pii: E57. https://doi.org/10.3390/jof3040057

Calderone, R. A., \& Fonzi, W. A., 2001. Virulence factors of Candida albicans. Trends Microbiol . 9(7), 327-335. https://doi.org/10.1016/S0966$\underline{842 X(01) 02094-7}$

Chen, C.-C., Kong, M.-S., Lai, M.-W., Chao, H.-C., Chang, K.-W., Chen, S.-Y.,

. Lin, P.-Y., 2010. Probiotics have clinical, microbiologic, and immunologic efficacy in acute infectious diarrhea. Pediatr Infect Dis J. 29(2), 135-138 http://doi: 10.1097/INF.0b013e3181b530bf

Cheng, M.-F., Yang, Y.-L., Yao, T.-J., Lin, C.-Y., Liu, J.-S., Tang, R.-B., Ho, M., 2005. Risk factors for fatal candidemia caused by Candida albicans and nonalbicans Candida species. BMC Infect Dis . 5(1), 22. http://doi:10.1186/14712334-5-22

Desai, P. R., Lengeler, K., Kapitan, M., Janßen, S. M., Alepuz, P., Jacobsen, I. D., \& Ernst, J. F., 2018. The 5'untranslated region of the EFG1 transcript promotes its translation to regulate hyphal morphogenesis in Candida albicans. mSphere. 3. pii: e00280-18. http://doi:\%2010.1128/mSphere.00280-18

Dewhirst, F. E., Chen, T., Izard, J., Paster, B. J., Tanner, A. C., Yu, W.-H., Wade W. G., 2010. The human oral microbiome. J Bacteriol. 192(19), 5002-5017 http://doi:\%2010.1128/JB.00542-10

Diaz, P. I., Strausbaugh, L. D., \& Dongari-Bagtzoglou, A., 2014. Fungalbacterial interactions and their relevance to oral health: linking the clinic and the 
bench. Front Cell Infect

Microbiol.

4 ,

101.

https://doi.org/10.3389/fcimb.2014.00101

Diaz, P. I., Xie, Z., Sobue, T., Thompson, A., Biyikoglu, B., Ricker, A., DongariBagtzoglou, A., 2012. Synergistic interaction between Candida albicans and commensal oral streptococci in a novel in vitro mucosal model. Infect Immun .80(2), 620-632. http://doi:\%2010.1128/IAI.05896-11

Elahi, S., Pang, G., Ashman, R., \& Clancy, R., 2005. Enhanced clearance of Candida albicans from the oral cavities of mice following oral administration of Lactobacillus acidophilus. Clin Exp Immunol.141(1), 29-36. http://dx.doi.org/10.1111/j.1365-2249.2005.02811.x

Fijan, S. (2014). "Microorganisms with claimed probiotic properties: an overview of recent literature." Int J Environ Res Public Health.11(5): 4745-4767. https://doi.org/10.3390/ijerph110504745

Freire, F., De Barros, P. P., Pereira, C. A., Junqueira, J. C., \& Jorge, A. O. C., 2018. Photodynamic inactivation in the expression of the Candida albicans genes ALS3, HWP1, BCR1, TEC1, CPH1, and EFG1 in biofilms. Lasers Med Sci .1-8. https://doi.org/10.1007/s1010

Gao, L., Xu, T., Huang, G., Jiang, S., Gu, Y., \& Chen, F., 2018. Ora microbiomes: more and more importance in oral cavity and whole body. Protein Cell. 1-13. https://doi.org/10.1007/s13238-018-0548-1

Gendreau, L., \& Loewy, Z. G., 2011. Epidemiology and etiology of denture stomatitis. J Prosthodont . 20(4), 251-260. https://doi.org/10.1111/i.1532 $\underline{849 X .2011 .00698 . X}$

Guarana, M., \& Nucci, M., 2017. Acute disseminated candidiasis with skin lesions: a systematic review. Clin Microbiol Infect. 24:246-250 https://doi.org/10.1016/j.cmi.2017.08.016

Guglielmetti, S., Taverniti, V., Minuzzo, M., Arioli, S., Stuknyte, M., Karp, M. \& Mora, D., 2010. Oral bacteria as potential probiotics for the pharyngeal mucosa. Appl Environ Microbiol .76(12), 3948-3958 https://doi:\%2010.1128/AEM.00109-10

Hager, C. L., \& Ghannoum, M. A., 2017. The mycobiome: Role in health and disease, and as a potential probiotic target in gastrointestinal disease. Dig Liver Dis. 49:1171-1176. https://doi.org/10.1016/j.dld.2017.08.025

Harriott, M. M., \& Noverr, M. C., 2011. Importance of Candida-bacteria polymicrobial biofilms in disease. Trends Microbiol. 19(11), 557-563. https://doi.org/10.1016/j.tim.2011.07.004

Hasslöf, P., Hedberg, M., Twetman, S., \& Stecksén-Blicks, C., 2010. Growth inhibition of oral mutans streptococci and candida by commercial probiotic lactobacilli-an in vitro study. BMC Oral Health. 10(1), 18 https://doi.org/10.1186/1472-6831-10-18

Hatakka, K., Ahola, A., Yli-Knuuttila, H., Richardson, M., Poussa, T., Meurman, J., \& Korpela, R., 2007. Probiotics reduce the prevalence of oral Candida in the elderly - a randomized controlled trial. J Dent Res. 86(2), 125-130. https://doi.org/10.1177/154405910708600204

Huang, G., Huang, Q., Wei, Y., Wang, Y., \& Du, H., 2018. Multiple roles and diverse regulation of the Ras/cAMP/Protein Kinase A pathway in Candida albicans. Mol Microbiol. https://doi:10.1111/mmi.14148

Ishijima, S. A., Hayama, K., Burton, J. P., Reid, G., Okada, M., Matsushita, Y., \& Abe, S., 2012. Effect of Streptococcus salivarius K12 on the in vitro growth of Candida albicans and its protective effect on oral candidiasis model. Oral Dis .AEM. 18:260-4. http://dx. doi: 10.1111/j.1601-0825.2011.01868.x

James, K., Macdonald, K., Chanyi, R., Cadieux, P., \& Burton, J., 2016. Inhibition of Candida albicans biofilm formation and modulation of gene expression by probiotic cells and supernatant. J Med Microbiol 65(4), 328-336 https://doi.org/10.1099/jmm.0.000226

Jiang, Q., Stamatova, I., Kari, K., \& Meurman, J. H., 2015. Inhibitory activity in vitro of probiotic Lactobacilli against oral Candida under different fermentation $\begin{array}{llll}\text { conditions. } & \text { Benef } & \text { 361-368 }\end{array}$ https://doi:org/10.3920/BM2014.0054

Kennedy, M. J., \& Volz, P. A., 1985. Effect of various antibiotics on gastrointestinal colonization and dissemination by Candida albicans Sabouraudia. 23(4), 265-273. https://doi:\%2010.1080/00362178585380391

Kheradmand, E., Rafii, F., Yazdi, M. H., Sepahi, A. A., Shahverdi, A. R., \& Oveisi, M. R., 2014. The antimicrobial effects of selenium nanoparticle-enriched probiotics and their fermented broth against Candida albicans. DARU . 22(1), 48. https://doi:\%2010.1186/2008-2231-22-48

Köhler, G. A., Assefa, S., \& Reid, G., 2012. Probiotic interference of Lactobacillus rhamnosus GR-1 and Lactobacillus reuteri $R C-14$ with the opportunistic fungal pathogen Candida albicans. Infect Dis Obstet Gynecol 636474. http://dx.doi.org/10.1155/2012/636474

Kolenbrander, P. E., Palmer Jr, R. J., Periasamy, S., \& Jakubovics, N. S., 2010 Oral multispecies biofilm development and the key role of cell-cell distance. Nat Rev Microbiol. 8(7), 471. https://doi:\%2010.1038/nrmicro2381

Koll, P., Mandar, R., Marcotte, H., Leibur, E., Mikelsaar, M., \& Hammarstrom L., 2008. Characterization of oral Lactobacilli as potential probiotics for oral health. Oral Microbiol Immunol. 23(2), 139-147. https://doi:\%2010.1111/j.1399302X.2007.00402.X

Kraft-Bodi, E., Jørgensen, M., Keller, M., Kragelund, C., \& Twetman, S., 2015. Effect of probiotic bacteria on oral Candida in frail elderly. J Dent Res 94(9_suppl), 181S-186S. https://doi:\%2010.1177/0022034515595950
Levison, M. E., \& Pitsakis, P. G., 1987. Susceptibility to experimental Candida albicans urinary tract infection in the rat. J Infect Dis. 155(5), 841-846. http://dx. doi.org/10.1093/infdis/155.5.841

Li, F., \& Palecek, S. P., 2003. EAP1, a Candida albicans gene involved in binding human epithelial cells. Eukaryot Cell. 2(6), 1266-1273. https://doi:\%2010.1128/EC.2.6.1266-1273.2003

Liu, Y., \& Filler, S. G., 2011. Candida albicans Als3, a multifunctional adhesin and invasin. Eukaryotic cell. 10(2), 168-173.

MANIK, A., \& BAHL, R., 2017. A review on oral candidal infection. J Adv Med Dent Sci Res . 5(3), 54. https://doi:\%2010.1128/EC.00279-10

Martori, E., Ayuso-Montero, R., Martinez-Gomis, J., Viñas, M., \& Peraire, M. 2014. Risk factors for denture-related oral mucosal lesions in a geriatric population. J Prosthet Dent . 111(4), 273-279. https://doi:\%2010.1016/j.prosdent.2013.07.015

Matsubara, V., Silva, E., Paula, C., Ishikawa, K., \& Nakamae, A., 2012. Treatment with probiotics in experimental oral colonization by Candida albicans in murine model (DBA/2). Oral Dis. 18(3), 260-264 https://doi:\%2010.1111/j.1601-0825.2011.01868.x

Mehta, M., \& Dave, M., 2018. Candidiasis-review of risk factor. IJCR. 10 :67838-40.

Mendonça, F. H. B. P., Santos, S. S. F. D., Faria, I. D. S. D., Gonçalves E Silva, C. R., Jorge, A. O. C., \& Leão, M. V. P., 2012. Effects of probiotic bacteria on Candida presence and IgA anti-Candida in the oral cavity of elderly. Braz Dent J. 23(5), 534-538. https://doi:\%2010.1590/s0103-64402012000500011

Montelongo-Jauregui, D., Srinivasan, A., Ramasubramanian, A., \& Lopez-Ribot, J., 2018. An In Vitro Model for Candida albicans-Streptococcus gordoni Biofilms on Titanium Surfaces. J Fungi (Basel) . 4(2), 66. https://doi: 10.3390/jof4020066

Montelongo-Jauregui, D., Srinivasan, A., Ramasubramanian, A. K., \& LopezRibot, J. L., 2016. An in vitro model for oral mixed biofilms of Candida albicans and Streptococcus gordonii in synthetic saliva. Front Microbiol. 7, 686 https://doi:\%2010.3389/fmicb.2016.00686

Morales, D. K., \& Hogan, D. A., 2010. Candida albicans interactions with bacteria in the context of human health and disease. PLoS Pathog. 6(4), e1000886. https://doi:\%2010.1371/journal.ppat.1000886

Morelli, L., \& Capurso, L., 2012. FAO/WHO guidelines on probiotics: 10 years $\begin{array}{llll}\text { later. } & \mathrm{J} & \mathrm{Clin} & \text { Gastroenterol. }\end{array}$ https://doi:\%2010.1097/MCG.0b013e318269fdd5

Orsi, C. F., Borghi, E., Colombari, B., Neglia, R. G., Quaglino, D., Ardizzoni, A., Blasi, E., 2014. Impact of Candida albicans hyphal wall protein 1 (HWP1) genotype on biofilm production and fungal susceptibility to microglial cells Microb Pathog . 69, 20-27. https://doi: 10.1016/j.micpath.2014.03.003

Radford, D., Challacombe, S., \& Walter, J., 1999. Denture plaque and adherence of Candida albicans to denture-base materials in vivo and in vitro. Crit Rev Ora Biol Med . 10(1), 99-116. https://doi: 10.1177/10454411990100010501

Rijkers, G. T., De Vos, W. M., Brummer, R.-J., Morelli, L., Corthier, G., \& Marteau, P., 2011. Health benefits and health claims of probiotics: bridging science and marketing. $\mathrm{Br} \mathrm{J}$ Nutr. 106(9), 1291-1296. https://doi: $\% 2010.1017 / \mathrm{S} 000711451100287 \mathrm{X}$

Salminen, S., et al. (1998). "Demonstration of safety of probiotics - a review". Int. J. Food Microbiol. 44(1-2): 93-106. https://doi:\%2010.1016/s0168 1605(98)00128-7

Sharkey, L. L., Mcnemar, M. D., Saporito-Irwin, S. M., Sypherd, P. S., \& Fonzi, W. A., 1999. HWP1 Functions in the Morphological Development of Candida albicans Downstream of EFG1, TUP1, and RBF1. J bacteriol. 181(17), 5273 5279.

Shirtliff, M. E., Peters, B. M., \& Jabra-Rizk, M. A., 2009. Cross-kingdom interactions: Candida albicans and bacteria. FEMS Microbiol Lett. 299(1), 1-8 https://doi:\%2010.1111/j.1574-6968.2009.01668.x

Shokryazdan, P., Jahromi, M. F., Navidshad, B., \& Liang, J. B., 2017. Effects of prebiotics on immune system and cytokine expression. Med Microbiol Immuno .206(1), 1-9. https://doi:\%2010.1007/s00430-016-0481-y

Staniszewska, M., Bondaryk, M., Malewski, T., \& Kurzatkowski, W., 2014 Quantitative expression of Candida albicans aspartyl proteinase genes SAP7, SAP8, SAP9, SAP10 in human serum in vitro. Pol J Microbiol, 63(1), 15-20.

Theberge, S., Semlali, A., Alamri, A., Leung, K. P., \& Rouabhia, M., 2013. C. albicans growth, transition, biofilm formation, and gene expression modulation by antimicrobial decapeptide KSL-W. BMC Microbiol.13(1), 246 https://doi.org/10.1186/1471-2180-13-246

Vilela, S. F., Barbosa, J. O., Rossoni, R. D., Santos, J. D., Prata, M. C., Anbinder, A. L., . . . Junqueira, J. C., 2015. Lactobacillus acidophilus ATCC 4356 inhibits biofilm formation by $C$. albicans and attenuates the experimental candidiasis in Galleria mellonellar $\quad$ Virulence. $6(1), \quad 29-39$. https://doi:\%2010.4161/21505594.2014.981486

Zavisic, G., Petricevic, S., Radulovic, Z., Begovic, J., Golic, N., Topisirovic, L. \& Strahinic, I., 2012. Probiotic features of two oral Lactobacillus isolates. Braz J Microbiol. 43(1), 418-428. https://doi:10.1590/S1517-83822012000100050

Zomorodian, K., Saharkhiz, J., Pakshir, K., Immeripour, Z., \& Sadatsharifi, A., 2018. The composition, antibiofilm and antimicrobial activities of essential oil of 
Ferula assa-foetida oleo-gum-resin. Biocatalysis and Agricultural Biotechnology. $14,300-304$.

2011. Zomorodian, K., Saharkhiz, M., Rahimi, M., Bandegi, A., Shekarkhar, G., Bandegani, A., . . Bazargani, A., Chemical composition and antimicrobial activities of the essential oils from three ecotypes of Zataria multiflora. Pharmacogn Mag. 7(25), 53. https://doi:\%2010.4103/0973-1296.75902

\section{Legend to Figures:}

Figure 1 Inhibition of Candida biofilm formation in different concentrations of $P$ acidilactici

Figure 2 Candida germ tube formation in different concentrations of $P$. acidilactici

Figure 3 Hyphal and mycelial form of untreated $C$. albicans in serum-enriched RPMI-1640 (a, b) and in serum-enriched RPMI-1640 containing $512 \mu \mathrm{g} / \mathrm{mL}$ of $P$. acidilactici $(\mathrm{c}, \mathrm{d})$

Figure 4 Fungal burden (log $10 \mathrm{CFU} / \mathrm{swab})$ of Candida on oral cavity of mice treated in different concentrations of $P$. acidilactici $(* \mathrm{p}$-value $<0.05$, ** p-value $\leq 0.001)$.

Figure 5 (a,b). Untreated control, significant inflammation and presence of $C$. albicans dispersed in tissue, lymphatic dilation, and edema (PAS,40x)

(c). Treated with $15 \mathrm{mg} / \mathrm{mL} P$. acidilactici, few inflammation and C. albicans (H\&E, 100x)

(d). Treated with $60 \mathrm{mg} / \mathrm{mL} P$. acidilactici absence of inflammation and $C$. albicans beginning of healing in tissue (H\&E,100x).

\section{Abbreviations}

ALS, agglutinin-like sequence; ATCC, American Type Culture Collection; CBS, CentraalBureau voor Schimmelcultures; CFU, colony forming unit; BHI, brain heart infusion; CLSI, Clinical and Laboratory Standards Institute; CFS, cell free supernatant; D.W., distilled water; cDNA, complimentary deoxyribonucleic acid; RNA, Ribonucleic acid; PAS, periodic acid-Schiff; H\&E, haemotoxylin and eosin; MIC, minimum inhibitory concentrations; PBS, phosphate-buffered saline; MOPS, 3-(N-morpholine) Propane Sulfonic Acid); SAP, secreted aspartyl proteinases; EFG1, enhanced filamentous growth protein 1; HWP1,hyphal cell wall protein; ACT, beta actin; EAP, enhanced activated protein 1; XTT, (2,3-bis(2-Methoxy-4-Nitro-5-Sulfophenyl)-2H-Tetrazolium-5-Carboxanilide);

QRT.PCR, quantitative real time polymerase chain reaction; GRAS, generally recognized as safe; HIV, human immunodeficiency virus; WHO, world health organization; GI, gastrointestinal tract; ,PTCC, persian type culture collection ; MRS, de man, rogosa and sharpe; RPMI-1640, roswell park memorial institute1640

\section{Highlights}

- $\quad P$. acidilactici inhibited the growth of candida species at different concentrations with a geometric mean of $78.01 \mu \mathrm{g} / \mathrm{ml}$.

- Biofilm and germ tube formation inhibited in the presence of $P$ acidilactici in a dose dependent manner.

- Reduction $C$. albicans CFUs in mice was observed following treatment with this probiotic bacterium compared to control group.

- Real-time PCR analysis of $C$. albicans yeast treated with different concentration of probiotic bacterium showed reduction in genes expression 